\title{
Other Orthodoxies or The Centring of the Margins: A Dialogue
}

\author{
Leila Sujir, Sarah Murphy
}

\section{D'autres doxa ou le centrage des marges: un dialogue}

Ceci est le texte en trois parties d'une performance lors d'un colloque académique "Border Blur" tenu à Calgary en 1989. Il y a d'abord une description de l'interaction des deux femmes en noir autour d'une question posée dans le dialogue: "Si l'on coince le texte entre les marges, par où est-ce que l'on entre dans le texte?" La femme en velours noir parle du langage qui origine du chaos. La femme en cuir noir met dans le projecteur une seule image, celle d'un texte féministe classique à partir duquel elle commence à écrire dans les marges. Ces notes en tant que suppléments sont excessives et dynamiques, déséquilibrant l'économie textuelle de textes et notes pour déborder dans les espaces blancs. La troisième partie se compose de ces notes superposées au texte absent, "Paramilitary Parafictions," sur la torture et le langage qui, par leur répétition insistante, redéfinissent les relations marge et centre comme métonymie des espaces occupés, des espaces textuels et politiques.

\section{The Moment/The Performance}

Two carefully costumed women walk up to the front of the room where a video monitor passes tape of streets filmed from a moving vehicle. Already we can tell that these streets are from a place other than here, somewhere else, moving fast, now, as the women occupy the centre, in the margins, watched, watching.

Two overhead projectors are turned on, and each woman sets onto them a group of transparencies placed, one over the other, incomprehensible. This question is asked: If you centre the margins, where do you enter the text? They wait.

The woman in black velvet, fingering the pearls about her neck, begins to speak. She speaks of waiting. Of the need to be in silence for 
language to arise. To form itself out of chaos, new, different. To notice itself. Finding the territory it has, unknowing, occupied.

The woman in black leather pulls off her riding gauntlets and removes all but one of her transparencies from the projector. The one that remains has no text. The space for the text is empty. But there is, in the bottom margin, a footnote. She underlines in red, what is written there. Her pen moving in silence. The footnotes speak of linguistics, and folklore, and torture. They annote a text, here, with us, indefinite, not yet arisen.

The tape of the streets plays on.

Now, the woman in black velvet stops speaking. The woman in black leather, slowly starts to speak. The rhythm becomes faster. She speaks of speaking. Of speaking and of speaking. Of never stopping speaking. Of speaking until language has moved to the edge of dissolution, has begun to say what has not yet been said. As she speaks, speaking.

The woman in black velvet is now silent. She takes all but one of her transparencies from the projector. On it is printed a classic feminist text. Slowly she starts to write in the margins. Ideas that challenge, and underline, and erase. Notes that change, and update and make different. Until all the space at the margins is taken up. Until the text is encroached upon. Until notes and texts start to know each other. To interact. To become in dialogue. To exceed themselves.

The tape of the streets plays on.

The women speak again. And yet again. About centres and margins. About occupied spaces. About presence and absence. About spaces yet to occupy.

The woman in black velvet will start to write marginal notes onto the current catalogues of academic publishing houses.

The woman in black leather will tell us of the title of the absent text: Paramilitary Parafictions.

The tape of the streets plays on.

The women stop speaking. They remove their transparencies from the overhead projectors.

The tape of the streets plays on. 


\section{Notes}

1. Although she acknowledges the initiating role of his torture and the three years he subsequently spent in jail, his wife concurs in that his definitive downward spiral was set off by his inability to acquire the new language. She also reports that she cannot get through to him on any level now, even in the language they share. "He seems to think that I haven't suffered. Just because I don't have the scars on my chest from the acid the way he does. Just because I have full use of my hands. But he doesn't know what I went through the time he was in jail either. When the death squads were looking for me and I had to dress as a prostitute just to get out of the place after I visited him. You should have seen me all tarted up and with a skirt up to here, that the real whores lent me. And then once they [the death squad] followed me and I got on a bus, the number two I think but I didn't know where it went, and when I got off at the end of the line it was a market and there was a shootout where some people died but they didn't get me and I felt so sorry but what could I do, or the time I went to visit my kids, I had them hidden by then and I had to hide inside a latrine all night. But that wasn't the worst of it, not even the smell. Because the twenty-one days he was disappeared I hunted among the corpses in the clandestine graveyards, you know about those, with my one year old on my back, I had nowhere to put her yet, and I don't know how to say it, you can't know about this, but there's a smell, so sweet, and no matter how many times you wash your clothes, you can't get rid of it." 
2. Translator's Note: There are many figures in Salvadoran folktales that can be looked upon as weakened Pre-Columbian gods or spirits of place, much the way leprechauns and fairies are the shrunken leftovers of the pre-Christian Celtic religions. One, La Ciguanava, is a llorona type figure, and may well be part of the same myth system as the legendary Mexican lady of that name, since the areas in which she occurs have the same myth and language base. She stands under trees crying, her rebozo wrapped about her. Sometimes she will follow men or walk ahead of them. One informant reported that La Ciguanava's position ahead or behind him dictated his luck in that night's fishing. Another such figure is El Cipitin, about whom less is known. He is seen as a child of about ten years who will come into the sugar cane mills to eat the ash that is left from the process of refinement, leaving his footprints in the morning. None of the informants seemed to know more about him, or the reasons behind his strange diet. 
Other Orthodoxies or The Centring of the Margins: A Dialogue $\cdot 77$

3. While his problems with the new language were manifest even in his classes, where he would seem to lack concentration, spending much time staring out windows or at points in space, or objects, they were apparently much worse at home. When he attempted to do written assignments, especially journal writing, he would become very agitated, complaining of headaches, screaming at his wife and children, or even hurling the textbooks across the room. "It really isn't right, to blame me, you know," his wife says. "I had to learn to speak. I was the one who went all over the city, even into the bars, to hunt down foreign journalists to make my denunciations. I told them all about him, about how he had disappeared about how he had been taken away about how I couldn't find him, it was during the civilian government when they were trying to look good internationally. That's how I started my work with the Human Rights Commission. And then I really learned. All the relevant words.

Disappearance, torture, corpse, mutilation, percentage. In it seemed like at least ten languages. I probably saved his life. I didn't want to show him up." 
4. Translator's Note: It is interesting that even in the devastated Salvadoran countryside one can note the laws of applied linguistics at work. Just as the Spanish 'peligro' (danger) derived from the Latin 'periculum' through compression and consonant reversal, we can see the same process at work on the rather sophisticated and until now little used word 'bombardeo' (bombardment). This word is now commonly said 'borbandeo,' achieving greater ease of pronunciation through both the consonant reversal and the opening of the ' $m$ ' into ' $n$ ' because of its proximity to the ' $d$.' Both the peasants who are the victims of the act it signifies and their well-educated advocates now say the word in this manner. We can only speculate that the final monument to the 70,000 dead in El Salvador's ten year civil war may be the permanent passing of the word 'borbandeo' into the Spanish lexicon. Or wonder what the effects of continued oral usage will be on the utterly foreign word 'napalm' (napalm). 
While it is generally acknowledged that first language acquisition quickly centres in one defined area of the left cerebral cortex, there is an increasing body of evidence to indicate that second language acquisition is more decentralized. Some part of the new lexicon may be located near the first language centre, while others may be located scattershot, even word by word, throughout the cerebral cortex. A secondary language centre may also develop in the brain's right hemisphere. It has been suggested that besides the words that exist in direct translation, transparent to the mind in both languages simultaneously, much vocabulary is segregated by language. Thus when the signifier is triggered into consciousness by direct or indirect apprehension (usually a visual image) of the signified, or at the end of a syntactical chain in one of the two languages, it still remains hidden, though known, in the other. The location of a word in left or right hemisphere may be tested through the blocking of one eye when the object is shown. It is the existence of two such parallel but unconnected lexicons that makes it possible for the authors to posit the existence of words or concepts so well hidden, and powerful in their effect on the subject, that they will sabotage those changes to personality and body language necessary to satisfactorily complete acquisition of a new target language, or even dictate a reactive blurring to the personality in the fully acquired language of which they should be a part. We are now beginning our search for these saboteurs in left and right brain, as well as in the body itself: the swollen tongue, the empty gums, the hard scarred skin, the twisted bones and unseeing eyes. We will then extend it to movement, to the mind and body at one in a tiny gesture or tone, that seems to bring on silence and the aborted moment of recall. 
6. Although she has been helpful to us in many areas, his wife is uncooperative in the area of her husband's hallucinations. An educated woman acquainted with both culture shock and the concept of Post Traumatic Stress Disorder and how it can trigger long after the event, as it often does in Vietnam Veteran's Syndrome, she nonetheless says that she too was brought up to believe in ghosts and in her country's folkloric figures. As she puts it, "Look, I grew up terrified of my dead grandmother rattling the dishes in the cupboard on the Day of the Dead just like everyone else did. And when a neighbour told me about the dog he saw as big as a pony with glowing red eyes salivating and baring his teeth down by the graveyard, well I didn't walk on that road for a long time. Still, after so many days and nights among the dead, turning the bodies over one by one, and sleeping among them with the death squad looking for me - they didn't come to haunt me. So I'm not afraid anymore. But if he says they come to haunt him, or that the Ciguanava walks with him, or El Cipitin has come to Canada to play with his children's shiny plastic toys, Jesus Christ, man, he has better reason than most. And if they whisper and share a private language the rest of us don't iknow, well, they go back a long way. Who are we to interrupt a conversation between such old friends?" 
Other Orthodoxies or The Centring of the Margins: A Dialogue $\cdot 81$

7. Juan Pablo Letelier, son of assassinated Chilean diplomat Orlando Letelier, speaking in Calgary, April 3, 1989. "Although none of the casualties were inflicted in conflicts between nation states [but rather, in conflicts along the internal ideological frontiers imposed by the national security state], it can be said that in the last decade we have lived a third world war in South America. You know those casualties. They walk here among us." 